\title{
Weak premating isolation between two parapatric brocket deer species
}

\author{
Juan Carranza a,b,c,*, Mar Roldán ${ }^{a}$, Ellen de Fátima Carvalho Peroni ${ }^{a}$, \\ José Maurício Barbanti Duarte ${ }^{a}$ \\ a Núcleo de Pesquisa e Conservação de Cervídeos (NUPECCE), Universidade Estadual Paulista (Unesp), Faculdade de Ciências Agrárias e Veterinárias, \\ Jaboticabal, Brazil \\ b Ungulate Research Unit, Cátedra de Recursos Cinegéticos y Piscícolas (CRCP), Universidad de Córdoba, 14071 Córdoba, Spain \\ ${ }^{\mathrm{c}}$ Facultad de Medicina Veterinaria y Zootecnia, Universidad Agraria del Ecuador, Guayaquil, Ecuador
}

\section{A R T I C L E I N F O}

\section{Article history:}

Received 17 August 2016

Accepted 14 February 2017

Handled by Luca Corlatti

Available online 25 May 2017

\section{Keywords:}

Premating barriers

Mazama

Copulation

Mating

Courtship behaviour

Mate choice

No-choice experiments

Hybridization

\begin{abstract}
A B S T R A C T
Brocket deer Mazama nemorivaga and M. gouazoubira occur at the Amazon basin and southern areas, respectively, in parapatric distribution ranges. Both species can interbreed in captivity, although hybrids have serious fertility problems. Therefore, we expect natural selection to favour behavioural barriers against interspecific mating. We carried out no-choice tests with individuals of both species in captivity, along with white-tailed deer (Odocoileous virginianus) as outgroup. Behaviours were video recorded and analysed by using Generalized Mixed models, with interacting females and males as random subjects. Trials never led to copulation when the white-tailed-deer male was involved. Copulations within brocket deer species were more likely to occur when the individuals belonged to the same species (82.4\%) but they also occurred quite frequently in interspecific interactions (35.7\%). We identified some courtship behaviours, in males and females, which associated with a higher copulation probability or showed differences in frequency when performed to partners of the same or different species. In conclusion, our results reveal that the occurrence of facilitating behaviours and copulations were more common in intraspecific interactions, evidencing discrimination between species, but also that the precopulatory barrier was not strong between both brocket deer species.
\end{abstract}

(c) 2017 Deutsche Gesellschaft für Säugetierkunde. Published by Elsevier GmbH. All rights reserved.

\section{Introduction}

Biological species are maintained by reproductive isolation (Dobzhansky, 1937; Schluter, 1998; Futuyma, 2005; Birkhead and Brillard, 2007). Isolation may be effective due to allopatric distribution, although in many cases, either because of secondary contact or due to the type of speciation process, closely related species occur in sympatry or parapatry. In such circumstances, it becomes especially relevant to study the behavioural or physiological mechanisms that can limit gene flow between them (Dobzhansky, 1937; Mayr, 1963). Regardless the nature of the mechanisms that originate genetic differentiation, once the sister species have split, heterospecific breeding is usually costly for both of them. Mating and breeding may entail costs in terms of time, resources invested,

\footnotetext{
* Corresponding author at: Núcleo de Pesquisa e Conservação de Cervídeos (NUPECCE), Universidade Estadual Paulista (Unesp), Faculdade de Ciências Agrárias e Veterinárias, Jaboticabal, Brazil.

E-mail address: jcarranza@uco.es (J. Carranza).
}

predatory or disease risks incurred, as well as rearing and providing care to offspring. These costs may have none or little return when offspring are unviable or less successful, and hybrids from interspecific breeding are commonly infertile or have less fitness than offspring from intraspecific breeding (Liou and Price, 1994).

For mammalian females, the production of hybrids may entail high costs of gestation and lactation that compromise mothers' success in the current breeding season as well as for an important proportion of their lifetime reproductive success. These costs of heterospecific matings are expected to fuel selection favouring individual strategies to discriminate among mating partners and reject as mates those that would give rise to less successful offspring (Trivers, 1972; Andersson, 1994).

Sexual signals during courtship (Andersson, 1994; Johnstone, 1997), such as visual displays or sex pheromones, play a crucial role as premating barriers between closely related taxa (Bradbury and Vehrencamp, 1998; Ptacek, 2000). But rejection of potential mates may also entail costs. For example, males and females may lose time, energy and mating opportunities when suitable partners are wrongly avoided. Male harassment may also increase the costs 


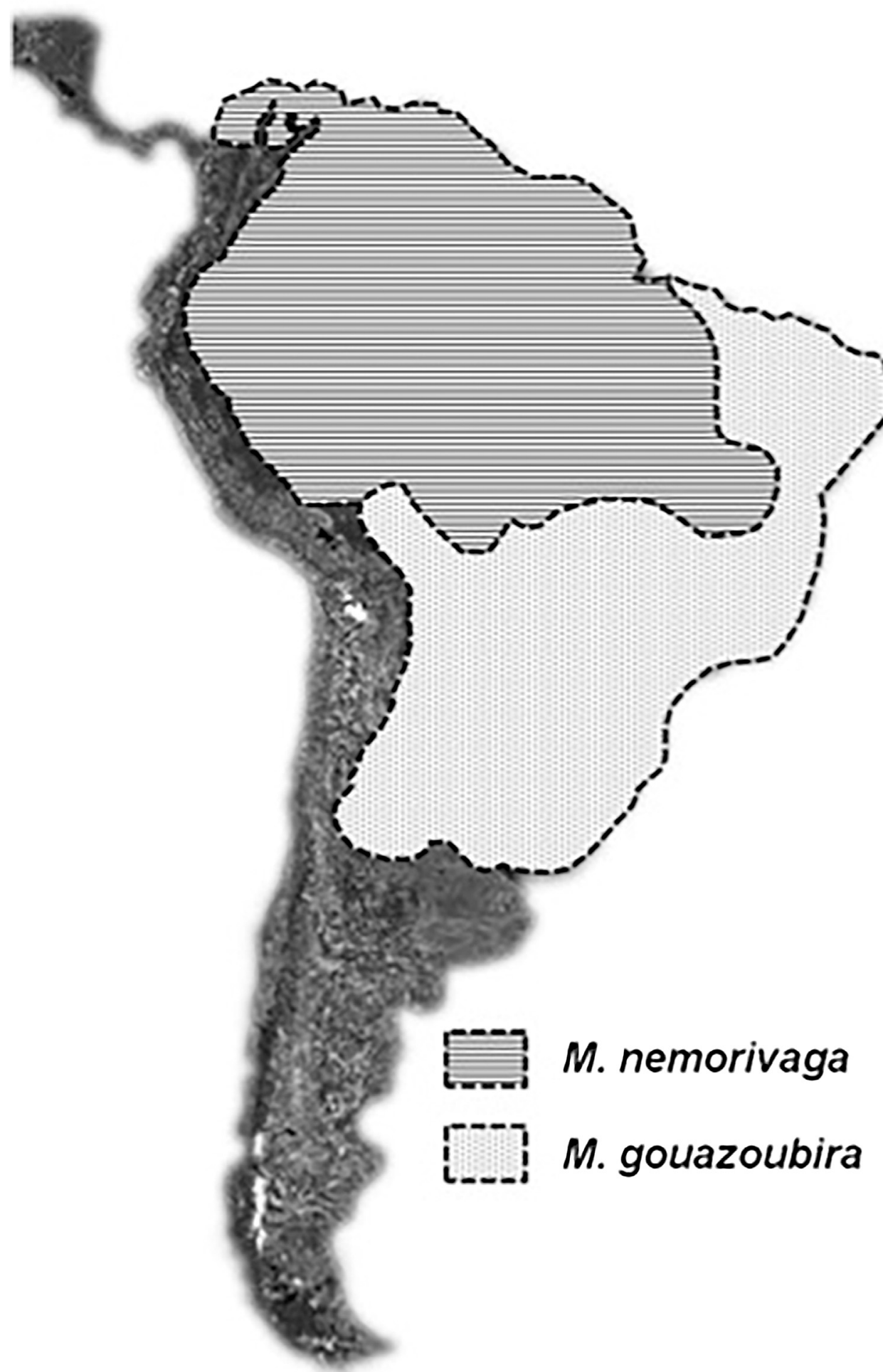

Fig. 1. Map showing the current accepted distribution ranges of both study species in South America (after Black-Decima et al., 2010; Rossi et al., 2010).

of mate rejection, so that females may be forced to accept copulations to save time, energy and risk of injuries from the males. However, acceptation by females may not be favoured by selection if leading to the allocation of significant maternal resources into unviable or low successful offspring. But also, the presence of effective barriers either at postcopulatory-prezygotic phase or at an early postzygotic stage when little investment has been allocated to the new embryo by the female, are expected to reduce the strength of selection for precopulatory barriers, i.e. favour female acquies- cence against male coercion (Parker and Birkhead, 2013). Likewise, pre- and post-copulatory traits tend to be negatively related in ungulates (Ferrandiz-Rovira et al., 2014).

Mazama nemorivaga and Mazama guazoubira are two cervid species that inhabit, respectively, the tropical rainforest in the Amazonian basin and drier forested habitats southwards from the Amazon to eastern and southern Brazil, Uruguay and northern Argentina (Fig. 1). Although a thoughtful sampling is lacking, it is assumed that their ranges do not have much overlapping but 
there is a long contact zone between the geographical distributions of both species, so that they are considered as parapatric species (Rossi and Duarte, 2008). Evolutionary divergence time between both species was estimated as high as 5 Mya (Duarte et al., 2008; see also Escobedo-Morales et al., 2016; Heckeberg et al., 2016). Their phenotypes are very similar, probably as a consequence of their evolutionary convergence during the adaptation to tropical forests in South America (Duarte et al., 2008), although they have developed neat differences in sperm features (Cursino and Duarte, 2016). Hybrids are not known in the wild but two of them were produced in captivity and proved to be viable until maturity but infertile (Martins, 2015).

Little is known on the courtship behaviour and mating system of these species. As forest dwellers, individuals are solitary and observations for $M$. gouazoubira suggest that females use mostly exclusive ranges with male ranges overlapping with those of more than one female. Males are probably territorial and females defend core parts of their ranges (Black-Decima, 2000). Females come into oestrus every 26.9 days on average, with 2.3 days as the mean oestrus duration (Pereira et al., 2006). Within each ovulation, females accept more than one copulation, at least in captive conditions (unpublished observations).

Heterospecific interactions may occur in the wild, at least along the contact zone. Here we focus on the behavioural barriers that could prevent gene flow between both species. In particular, our goal was to study courtship behaviour of captive pairs at homo- and heterospecific mating trials, as a pre-mating barrier contributing to reproductive isolation between both species.

We were interested in testing by an experimental procedure whether the two brocket deer species are fully reproductively isolated and will not engage in inter-specific courtship behaviour and mating. Also, by using a more distant species as a control (in this case a white-tailed deer male Odocoileous virginianus) we would expect that the lack of reproductive behavioural response to heterospecific mates would be similar either towards the other brocked deer species or towards the control species. Alternatively, premating isolation may be partial rather than complete. The prediction is that individuals will display a less intense response to heterospecific mates with even certain lower probability of copulation, while they will maintain no sexual response to the more distant, control species. The null hypothesis is that there are no differences in the behaviour and copulation probability, either for males or for females, towards homospecific and heterospecific mates.

Additionally, we will also observe whether behaviour after an eventual copulation may differ between homo- and heterospecific pairs, as a complementary source of information on actual discrimination between species.

\section{Material and methods}

\section{Animals}

The study used seventeen adult animals from two brocket deer species, eight females (aged 3.5-6-years-old, 16-23 kg body weight) and five males (aged 2.5-5-years-old, $16-25 \mathrm{~kg}$ body weight) from $M$. gouazoubira and three females (4-7-years-old, $14.5-16 \mathrm{~kg}$ body weight) and one male (aged 2.5 -years-old, $15 \mathrm{~kg}$ body weight) from $M$. nemorivaga. Some of these animals were born in the research centre (two M. gouazoubira males: Bill and Juan; and one $M$. nemorivaga: Giovanni), although most of them originated from confiscations, either directly sent by the authorities to the research centre or after spending some period in a zoo. Animals were maintained in individual indoor stalls visually isolated from one another, although they probably got olfactory information from each other since all of them were kept in the same building. All females had previous experience with males, albeit variable, either from mating or simply from having physical proximity when assessing their oestrus status. For males, only Sensato ( $M$. gouazoubira from a zoo) had some previous experience with females at the beginning of the experiments. Despite its limited informative value and accuracy, we explored the effect of the binary variable "Male previous experience (yes, no)" in the analyses, and since it had no effect we decided not to use it.

Animals were housed individually in indoor holding areas all day (individual stalls of $12 \mathrm{~m}^{2}$ ) at the Deer Research and Conservation Centre (NUPECCE) of the Department of Animal Science of the FCAV-UNESP in Jaboticabal, São Paulo, Brazil. Animals from both species were fed ad libitum with a diet consisting of a pelleted feed ( $12 \%$ crude protein, $2 \%$ crude fat, $10 \%$ crude fibre; Purina Co., Paulínia, Brazil) and approximately $1 \mathrm{~kg} / \mathrm{animal} /$ day of fresh alfalfa (Medicago sativa), perennial soybean (Neonotonia wightii), or mulberry branches (Morus alba). Drinking water was available ad libitum. The present study was approved by the Animal Ethics and Welfare Committee (Comitê de Ética e Bem-estar Animal, CEBEA) of the School of Agricultural and Veterinary Sciences (Faculdade de Ciências Agrárias e Veterinárias, FCAV) of São Paulo State University (UNESP), Jaboticabal, SP, Brazil.

\section{Experimental procedure}

We conducted no-choice mating trials, where an oestrous female was sequentially exposed to different males. The order of the sequence of males was interchanged in successive oestrus for the same female. We aimed to test every individual male and female with partners from both the same and different species. However this was not always possible due to limitations in available individuals and mortality of some specimens during the time when experiments were going on.

The use of 2-choice or no-choice experimental procedures to test female preferences has been recently reviewed by Dougherty and Shuker (2015), highlighting the importance of the species ecology for the selection of the best experimental design. In the case of species in which females are unlikely to encounter more than one mate at a time and multiple matings occur only by contacting sequentially with potential mates, as it is the case for Mazama species, the no-choice design may be more appropriate to reduce bias in the estimation of female preferences (see also Ryan and Tailor, 2015).

\section{Manipulation of animals and conducting mating trials}

We carried out 93 mating trials, involving 6 males and 10 females of both species, along with 7 control trials with a male of the outgroup species Odocoileous virginianus. The white tailed deer male was only presented to $M$. gouazoubira females.

For the trials, one male was herded along the corridor to the stall with the female, the door was left open to let the male enter on his own. We then closed the door and recorded during approximately fifteen minutes (arbitrary time, but based on previous observations that indicated that it was enough to allow mating behaviour until the intensity of interactions noticeably decreased) with a video camera placed in an elevated position over the wall of the stall. Although we intended to maintain the same duration time of $15 \mathrm{~min}$ for recorded sequence in all trials, it had to be interrupted in cases of clear rejection with aggressive behaviour or any other circumstances undesirable from the point of view of the welfare of animals.

Females were used in trials when in oestrus. The oestrus was natural or induced. To detect oestrus, females were monitored daily by an examiner, and in some doubtful cases we used a male to see 
the reaction of the female. Behavioural oestrus was characterized by an increase of cervical mucus production, as well as by the lack of reflex reaction to the pressure in the pelvic region by the examiner (Curlewis et al., 1988; Zanetti et al., 2010) or when remaining still while the male attempted to court and mount her. After the first natural oestrus of a female, we normally induced subsequent cycles by applying $265 \mu \mathrm{g}$ cloprostenol ( $1 \mathrm{~mL}$ Ciosin; Schering Plough Coopers, Brazil), a synthetic analogues of prostaglandin F2 alpha to provoke the regression of corpora lutea and restart the oestrus cycle (Shah et al., 2014).

\section{Courtship and mating behaviours}

Courtship interactions normally started with the male approaching the female. He usually headed towards her anogenital region and performed olfactory inspection. The hind might stay, withdraw or even run when this behaviour starts. After this olfactory inspection by the male, he generally showed the flehmen response. Frequently, flehmen was also performed after the femaleís urine olfaction. In case of acceptance, the hind tended to stand firmly and move her tail while the male displayed courtship behaviour and attempted to mount her.

We considered two periods within the trial, the pre-copulation period and, if copulation happened, the post-copulation period. After a post-copulation period, animals may engage again in courtship behaviours that sometimes leed to more than one copulation within the same trial. Those periods when they pursued further copulations were also recorded as pre-copulation, and the beginning of these periods was identified by a significant change in their behaviour, normally by the male.

The behavioural patterns used in this study were based on our own preliminary observations and those described in the literature (Tomkins and Bryant, 1974; Samsudewa and Capitan, 2011; Morales-Piñeyrua and Ungerfeld, 2012).

For males, mating behaviours were:

- Anogenital: male approached with his nose to the anogenital area of the female and either sniffed or licked.

- Licking: licking areas of the body, normally head, ears, neck (anogenital excluded here). It may be mutually performed by both partners.

- Initiating contact: the focal individual starts some non-aggressive interaction within courtship.

- Searching: from a separate position, the focal individual walks towards the other partner.

- Tongue flick: repeated tongue extension and retraction.

- Mounting attempts: male attempts to mount females, even from her side or head but commonly from the rear quarters by jumping on her back and placing his slightly bent forelegs on her flanks. No intromission of the penis occurs.

- Flehmen: male flehmen response by which scents are transferred to the vomeronasal organ. The male curls back its upper lips exposing its front teeth, inhales with the nostrils usually closed, often holding this position for several seconds.

- Copulation: mounting including penis intromission and ejaculation. It was identified by the sudden movement of the male's pelvic area.

For females, the recorded behaviours were:

- Initiating contact: the focal individual starts some non-aggressive interaction within courtship.

- Searching: from a separate position, the focal individual walks towards the other partner.

- Tongue flick: tongue extension and retraction.
- Licking: licking areas of the body, normally head, ears, neck. It may be mutually performed by both partners.

- Squatting: the hind adopted the urination or defecation posture and generally urinated or defecated.

- Tail: tail fanning. Repeated movement of the tail in a horizontal plane. During motion, the tail typically was slightly lifted.

Rejection behaviours by the female may include aggression and avoidance (fleeing) in response of male approaching and courting/mounting. These behaviours were finally not included in the analyses because: (i) for aggression, they motivated the end of the trial, so we have no comparable frequencies, and (ii) for avoidance behaviours, they were negatively collinear with the included courtship behaviours or highly depended in their frequency to males' rather than females' behaviour.

\section{Statistical analyses}

For data analysis we used Generalized Linear Mixed Models as implemented in SPSS v.20 (SPSS, Chicago, IL, U.S.A.). Our data file had one line per individual in a trial, hence two lines per mating trial, one for the male and another for the female.

We performed three types of models. First, we were interested in looking at the copulation outcome in trials with the different combinations of mating pairs and depending on whether they both belong to the same or different species. In this case we selected cases for one of the sexes to run the analysis, since the outcome was common to both individuals of the pair. Secondly, we were interested in the number of copulations per trial depending on whether the partners belonged to the same or different species. And third, we were interested in the behaviours performed either by the male or by the female in the mating pair that associated with an outcome of copulation, or that occurred when both partners belonged to the same or different species. To perform those analyses we selected male cases or female cases, respectively.

Response variable was binary for the analyses with copulation (yes, no) and same species (yes, no) as dependent variables. In these cases we used binomial distribution with Logit link function. When the response variable was the number of copulations, the distribution used was negative binomial with a log link. Random subjects were in all cases individual females nested within males and the random effect covariance type was 'variance components'. When independent factors were behavioural patterns, they were introduced as absolute frequencies or time in seconds, and always the duration in seconds of the observation period was also included as a control covariate. Only for descriptive purposes, we provided in text means and SD per minute of raw data for some behaviours. We used the analytical options that the SPSS package offers for GLMM to deal with data limitations, namely (1) variable degrees of freedom across tests (Satterthwaite approximation), and (2) robust covariance estimations for the tests of fixed effects. All the main fixed effects were kept in the final model except in case of collinerarity. Collinearity between covariates was treated firstly by inspection of correlation matrix, and when the Spearman correlation coefficient was higher than 0.60 we chose the variable that resulted in the smaller information criterion values (Akaike and Bayesian Criteria).

\section{Results}

\section{Copulations in homospecific and heterospecific trials}

The outcome of the mating trials for homospecific and heterospecific pairs for both species and the control is shown in Fig. 2. Copulations never took place with the control species, the whitetailed deer, and the rejection responses by the M. gouazoubira 


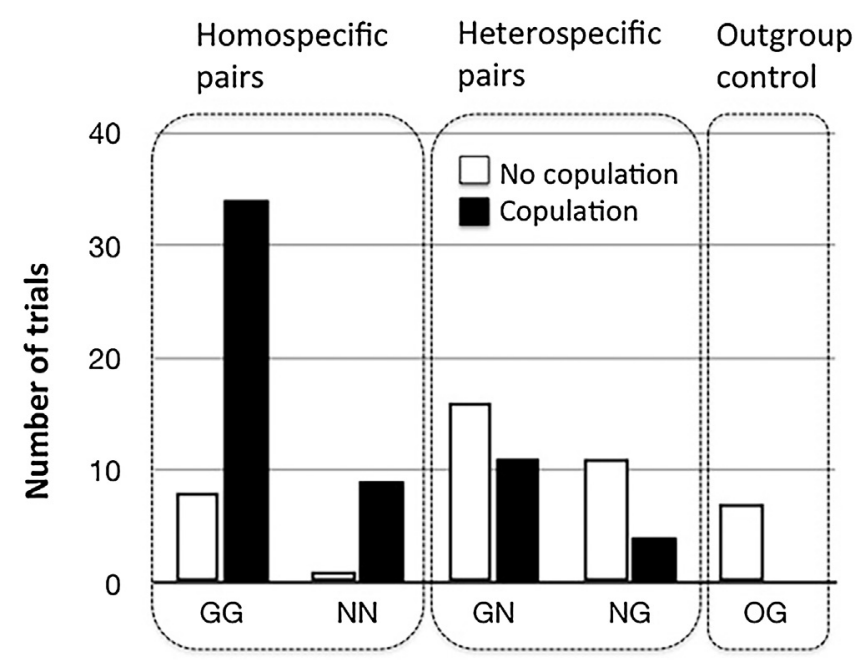

Species names of mating pairs (male, female)

Fig. 2. Frequency distribution of trials with and without any copulation for the different groupings of males and females of both study species and the outgroup control. Species pairs references: G: M. gouazoubira; N: M. nemorivaga; O: Odocoileous virginianus.

females occurred evidently in all 7 trails. As a result we decided not to conduct further control trials. For the two brocket deer species, copulations occurred in 42 out of 51 (82.4\%) trials involving homospecific pairs and in 15 out of 42 (35.7\%) involving heterospecific pairs.

Despite the fact that copulation took place in both homospecific and heterospecific pairs, it was more probable in homospecific pairs (Table 1 ). The period of day (morning or afternoon) had no effect in the results and hence it was not included in further analyses.

When the four combinations of both brocked deer species were introduced as a factor in the analysis (i.e. for M. gouazoubira, G, and $M$ nemorivaga, N: GG, GN, NG, NN), none of them resulted significant, indicating no effect of particular combinations beyond the homospecific or heterospecific nature of the pairs. When we introduced the two heterospecific pairs (GN, NG), i.e. when the female was $M$. gouazoubira or $M$. nemorivaga, none of them were significant, indicating no evidence for asymmetrical preferences to heterospecific males by females of both species (Table 2; Fig. 3).

Pairs may copulate more than once per mating trial. The number of copulations per trial ranged from 0 to 4 . The frequency distribution peaked at zero for heterospecific pairs and at one for homospecific pairs (Fig. 4), and both distributions significantly differed (Table 3), so that although heterospecific pairs can also perform several copulations per trial, its number was higher when pairs were homospecific compared to heterospecific.

\section{Which behaviours predicted a copulation outcome?}

The behaviour of males and females during the trial period before any copulation took place, were included as predictors in respective GLMM analyses with Copulation as the dependent variable and individual females nested within males as subjects, as well as the duration time of this period as a control covariate. In both models, for male and female behaviours, random factor male*female resulted non-signifficant, and the duration of precopulation period was shorter when copulation occurred (see Tables 4 and 5 below).

For males, Searching, Initiating contact, Licking and Mounting were highly correlated (Spearman rho >0.7). Among them, the behaviour that produced a better model on the basis of information criteria was Initiating. We conducted the model with Duration

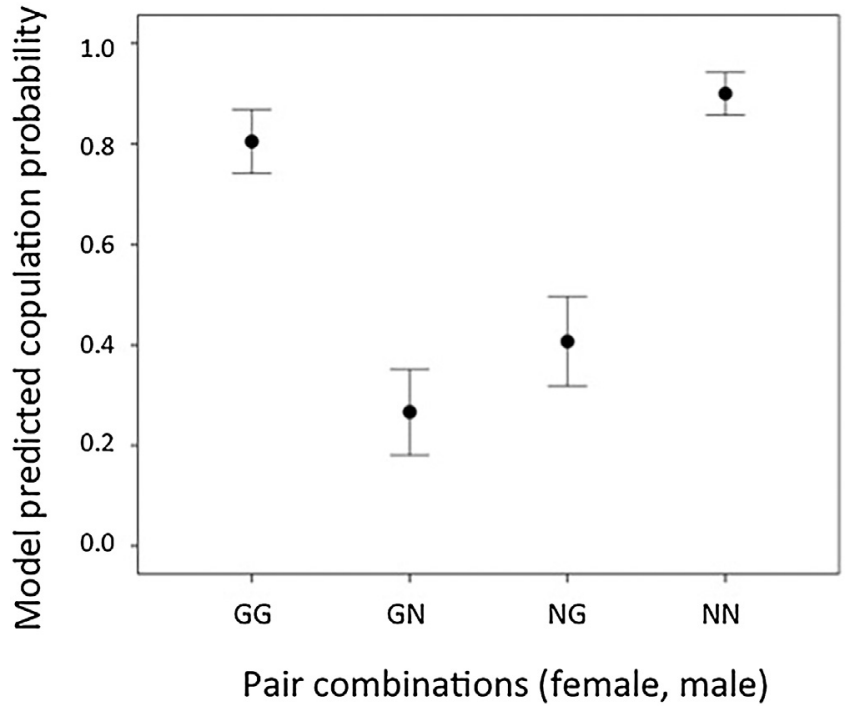

Fig. 3. Model based predicted probability of copulation for mating pairs as a function of pair composition (female, male) of both species (G: M. gouazoubira; N: $M$. nemorivaga). Predicted values from model of Table 2. Bars represent mean $\pm 95 \%$ confidence intervals.

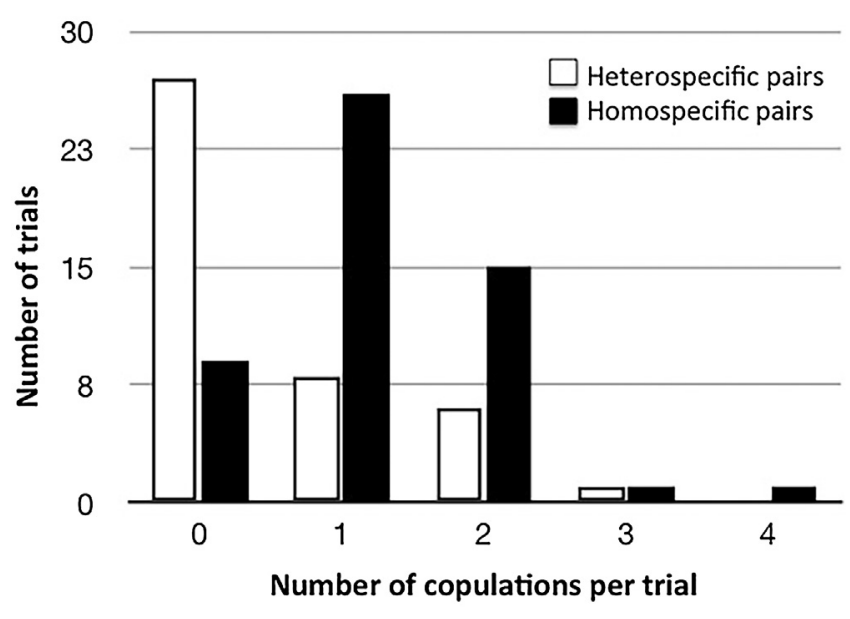

Fig. 4. Frequency distribution of number of copulations per trial for heterospecific and homospecific pairs.

of the pre-copulation period, Initiating, Anogenital, Tongue flick and Flehmen (Table 4). The results show that Initiating contact by the male was higher in trials that ended with a copulation outcome (raw data per minute, mean \pm SD: $0.98 \pm 0.76$ vs. $0.27 \pm 0.47$ ), and its correlated behaviours also showed signifficant effects on copulation when used one by one instead of Initiating (not shown).

For females, registered behaviours in the pre-copula period of trials did not show collinearity. GLMM model showed that female behaviours Initiating contact, Searching, Tail fanning and Squatting positively related to a copulation outcome (Table 5). Females never initiated contact in trials without copulation, and raw frequency per minute was $0.02 \pm 0.09$ SD in trials that ended with copulation.

Did male and female behaviour differ when performed to mates of the same or different species?

\section{During the pre-copulation period}

GLMMs with the behaviours of males and females before any copulation had taken place, and with the partner belonging to the same or to different species as the binary dependent variable, 
Table 1

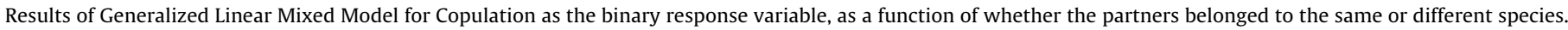

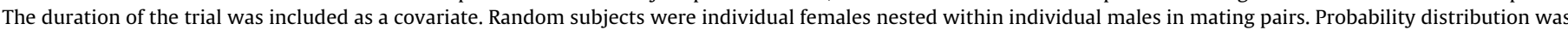

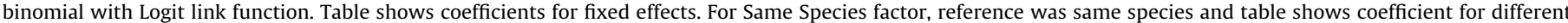
species (No Same Sp). Model accuracy 81.7\%. Random effects: males*females: Variance $\pm S E=1.272 \pm 0.908, Z=1.401 ; P=0.161$. N=93 cases.

\begin{tabular}{|c|c|c|c|c|c|c|}
\hline \multirow[t]{2}{*}{ Model term } & \multirow[t]{2}{*}{ Coefficient } & \multirow[t]{2}{*}{ Std. Error } & \multirow[t]{2}{*}{$\mathrm{t}$} & \multirow[t]{2}{*}{ Sig. } & \multicolumn{2}{|l|}{$95 \% \mathrm{CI}$} \\
\hline & & & & & Lower & Upper \\
\hline Intercept & -1.240 & 0.757 & -1.638 & 0.111 & -2.779 & 0.299 \\
\hline Duration. & 0.004 & 0.001 & 3.834 & $<0.001$ & 0.002 & 0.006 \\
\hline No Same Sp & -2.559 & 0.710 & -3.604 & 0.001 & -4.021 & -1.097 \\
\hline
\end{tabular}

Table 2

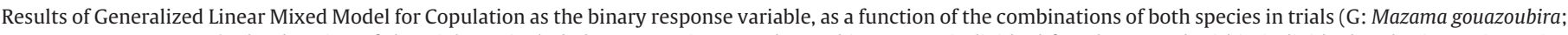

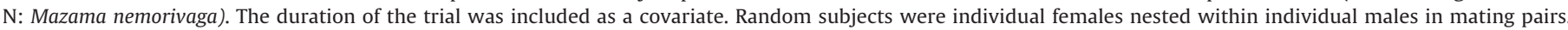

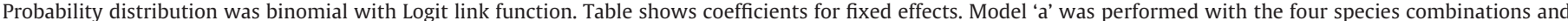

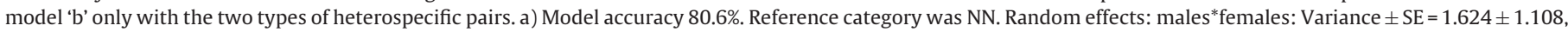

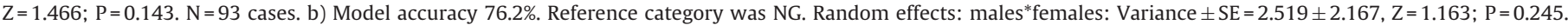
$\mathrm{N}=42$ cases.

\begin{tabular}{|c|c|c|c|c|c|c|}
\hline \multirow[t]{2}{*}{ Model term } & \multirow[t]{2}{*}{ Coefficient } & \multirow[t]{2}{*}{ Std. Error } & \multirow[t]{2}{*}{$\mathrm{t}$} & \multirow[t]{2}{*}{ Sig. } & \multicolumn{2}{|l|}{$95 \% \mathrm{CI}$} \\
\hline & & & & & Lower & Upper \\
\hline \multicolumn{7}{|l|}{ Model a) } \\
\hline Intercept. & -0.780 & 0.751 & -1.039 & 0.616 & -273.954 & 272.394 \\
\hline Duration & 0.004 & 0.001 & 3.823 & $<0.001$ & 0.002 & 0.006 \\
\hline GG (NN) & -0.512 & 0.504 & -1.016 & 0.840 & $-88,485.42$ & $88,484.40$ \\
\hline GN (NN) & -3.405 & 0.601 & -5.668 & 0.664 & $-93,178.88$ & $93,172.07$ \\
\hline NG (NN) & -2.951 & 0.726 & -4.067 & 0.411 & $-1,123.19$ & $1,117.29$ \\
\hline \multicolumn{7}{|l|}{ Model b) } \\
\hline Intercept & -3.498 & 0.939 & -3.725 & 0.017 & -6.004 & -0.993 \\
\hline Duration & 0.003 & 0.001 & 3.617 & 0.004 & 0.001 & 0.006 \\
\hline GN (NG) & -0.510 & 0.986 & -0.517 & 0.659 & -5.034 & 4.014 \\
\hline
\end{tabular}

\section{Table 3}

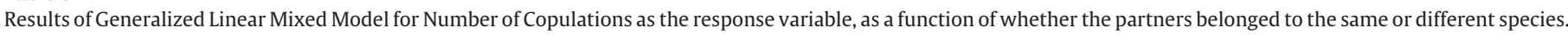

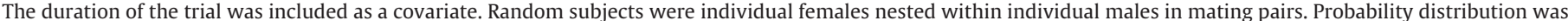

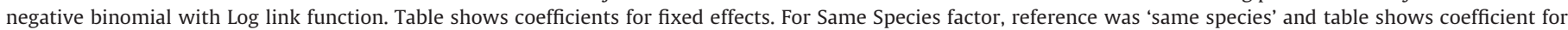
'different species' (No Same Sp). Random effects: males*females: Variance $\pm S E=0.308 \pm 0.266, Z=1.157 ; P=0.247$. $N=93$ cases.

\begin{tabular}{|c|c|c|c|c|c|c|}
\hline \multirow[t]{2}{*}{ Model term } & \multirow[t]{2}{*}{ Coefficient } & \multirow[t]{2}{*}{ Std. Error } & \multirow[t]{2}{*}{$\mathrm{t}$} & \multirow[t]{2}{*}{ Sig. } & \multicolumn{2}{|l|}{$95 \% \mathrm{CI}$} \\
\hline & & & & & Lower & Upper \\
\hline Intercept & -1.087 & 0.212 & -5.123 & 0.042 & -2.073 & -0.101 \\
\hline Duration. & 0.002 & 0.000 & 5.235 & $<0.001$ & 0.001 & 0.002 \\
\hline No Same Sp & -0.948 & 0.271 & -3.494 & 0.001 & -1.487 & -0.409 \\
\hline
\end{tabular}

\section{Table 4}

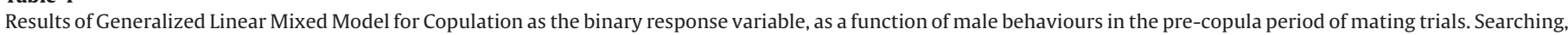

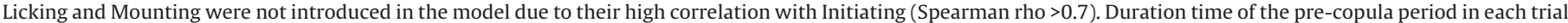

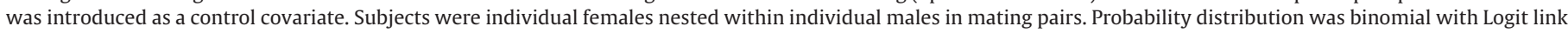
function. Table shows coefficients for fixed effects. Model accuracy $86.0 \%$. Random effects: males*females: Variance $\pm S E=1.931 \pm 1.377, Z=1.402 ; \mathrm{P}=0.161 . \mathrm{N}=93$ cases.

\begin{tabular}{|c|c|c|c|c|c|c|}
\hline \multirow[t]{2}{*}{ Model term } & \multirow[t]{2}{*}{ Coefficient } & \multirow[t]{2}{*}{ Std. Error } & \multirow[t]{2}{*}{$\mathrm{t}$} & \multirow[t]{2}{*}{ Sig. } & \multicolumn{2}{|l|}{$95 \% \mathrm{CI}$} \\
\hline & & & & & Lower & $\overline{\text { Upper }}$ \\
\hline Intercept & 1.610 & 0.669 & 2.406 & 0.020 & 0.265 & 2.955 \\
\hline Duration Pre. & -0.004 & 0.001 & -3.785 & $<0.001$ & -0.006 & -0.002 \\
\hline Initiating & 0.189 & 0.076 & 2.501 & 0.014 & 0.039 & 0.339 \\
\hline Anogenital & 0.028 & 0.016 & 1.750 & 0.087 & -0.004 & 0.060 \\
\hline Tongue flick & -0.013 & 0.015 & -0.835 & 0.406 & -0.042 & 0.017 \\
\hline Flehmen & 0.161 & 0.184 & 0.876 & 0.385 & -0.207 & 0.529 \\
\hline
\end{tabular}

showed that the random factor males*females was significant in both models, i.e. for male and female behaviours (Tables 6 and 7).

For males (Table 6), duration of the pre-copula period was shorter and males performed more Initiating and Anogenital behaviours when partners belonged to the same species (raw data per minute, mean \pm SD: $0.98 \pm 0.77$ vs. $0.37 \pm 0.58$ ). Like Initiating, correlated behaviours Searching, Licking and Mounting also were significant when introduced in the model one by one instead of Initiating (not shown). For females (Table 7), Anogenital (raw data per minute, mean \pm SD: $0.44 \pm 17$ vs. $0.04 \pm 0.15$ ) and Search- ing $(0.12 \pm 0.28$ vs. $0.01 \pm 0.05)$ were more frequently performed to mates of the same species while Tongue flick was slightly less common in homospecific trials ( $0.15 \pm 0.39$ vs. $0.16 \pm 0.23$; Table 7$)$.

\section{After copulation}

During the post-copula period, male and female behaviours to partners of the same or different species showed high interindividual variability, so that the random factor male*females was significant in both models (Tables 8 and 9). For males (Table 8), no behaviour resulted significantly different between homospecific 
Table 5

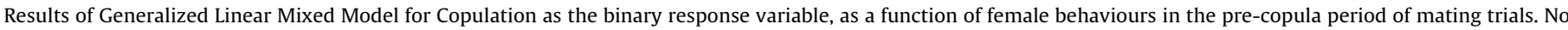

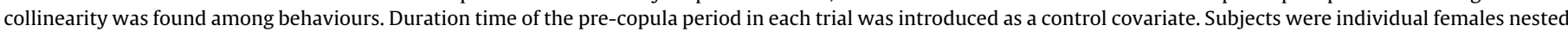

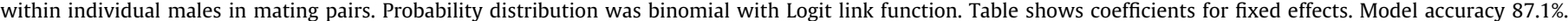
Random effects: males*females: Variance $\pm S E=1.396 \pm 1.125, Z=1.241 ; P=0.215 . N=93$ cases.

\begin{tabular}{|c|c|c|c|c|c|c|}
\hline \multirow[t]{2}{*}{ Model term } & \multirow[t]{2}{*}{ Coefficient } & \multirow[t]{2}{*}{ Std. Error } & \multirow[t]{2}{*}{$\mathrm{t}$} & \multirow[t]{2}{*}{ Sig. } & \multicolumn{2}{|l|}{$95 \% \mathrm{CI}$} \\
\hline & & & & & Lower & Upper \\
\hline Intercept & 1.204 & 0.755 & 1.594 & 0.115 & -0.298 & 2.707 \\
\hline Duration Pre. & -0.004 & 0.001 & -2.826 & 0.006 & -0.006 & -0.001 \\
\hline Initiating & 11.598 & 0.587 & 19.761 & $<0.001$ & 9.644 & 13.552 \\
\hline Anogenital & 0.127 & 0.117 & 1.080 & 0.283 & -0.107 & 0.360 \\
\hline Licking & 0.237 & 0.237 & 0.167 & 1.417 & 0.165 & -0.102 \\
\hline Search & 1.318 & 1.318 & 0.343 & 3.839 & 0.004 & 0.544 \\
\hline Tongue flick & -0.051 & 0.161 & -0.316 & 0.753 & -0.371 & 0.269 \\
\hline Tail & 0.045 & 0.045 & 0.022 & 2.109 & 0.038 & 0.003 \\
\hline Squatting & 0.653 & 0.246 & 2.650 & 0.010 & 0.161 & 1.145 \\
\hline
\end{tabular}

Table 6

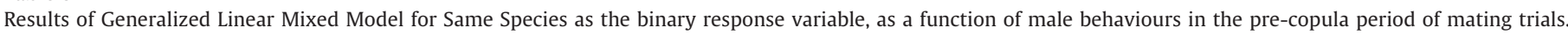

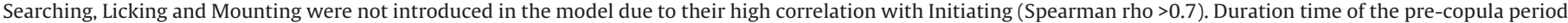

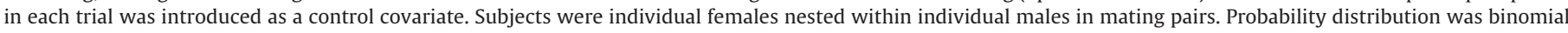

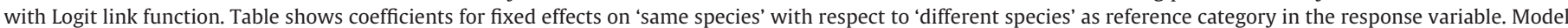
accuracy $100.0 \%$. Random effects: males*females: Variance $\pm S E=7.802 \pm 3.341, Z=2.335 ; P=0.020 . N=93$ cases.

\begin{tabular}{|c|c|c|c|c|c|c|}
\hline \multirow[t]{2}{*}{ Model term } & \multirow[t]{2}{*}{ Coefficient } & \multirow[t]{2}{*}{ Std. Error } & \multirow[t]{2}{*}{$\mathrm{t}$} & \multirow[t]{2}{*}{ Sig. } & \multicolumn{2}{|l|}{$95 \% \mathrm{CI}$} \\
\hline & & & & & Lower & Upper \\
\hline Intercept & 0.614 & 0.766 & 0.801 & 0.434 & -1.007 & 2.235 \\
\hline Duration Pre. & -0.003 & 0.001 & -2.841 & 0.009 & -0.005 & -0.001 \\
\hline Initiating & 0.168 & 0.070 & 2.391 & 0.020 & 0.028 & 0.309 \\
\hline Anogenital & 0.037 & 0.014 & 2.605 & 0.035 & 0.004 & 0.070 \\
\hline Tongue flick & -0.005 & 0.014 & -0.370 & 0.714 & -0.033 & 0.023 \\
\hline Flehmen & 0.177 & 0.163 & 1.086 & 0.292 & -0.167 & 0.521 \\
\hline
\end{tabular}

Table 7

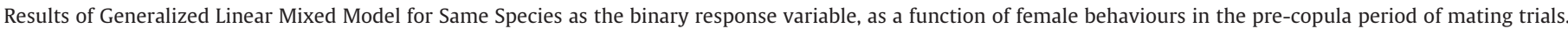

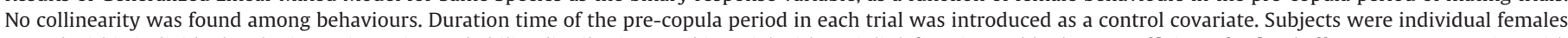

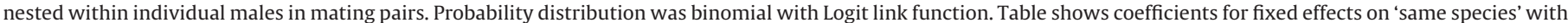

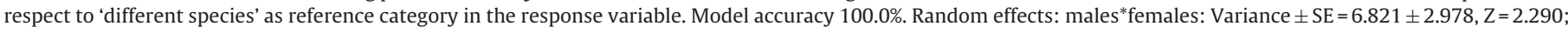
$\mathrm{P}=0.022$. $\mathrm{N}=93$ cases.

\begin{tabular}{|c|c|c|c|c|c|c|}
\hline \multirow[t]{2}{*}{ Model term } & \multirow[t]{2}{*}{ Coefficient } & \multirow[t]{2}{*}{ Std. Error } & \multirow[t]{2}{*}{$\mathrm{t}$} & \multirow[t]{2}{*}{ Sig. } & \multicolumn{2}{|l|}{$95 \% \mathrm{CI}$} \\
\hline & & & & & Lower & Upper \\
\hline Intercept & 0.631 & 0.854 & 0.738 & 0.470 & -1.162 & 2.423 \\
\hline Duration Pre. & -0.002 & 0.001 & -1.643 & 0.115 & -0.004 & 0.000 \\
\hline Initiating & -1.644 & 1.373 & -1.197 & 0.246 & -4.524 & 1.237 \\
\hline Anogenital & 0.346 & 0.171 & 2.026 & 0.066 & -0.027 & 0.720 \\
\hline Licking & 0.367 & 0.367 & 0.515 & 0.713 & 0.485 & -0.716 \\
\hline Search & 1.929 & 1.929 & 0.672 & 2.868 & 0.023 & 0.351 \\
\hline Tongue flick & -0.360 & 0.135 & -2.670 & 0.015 & -0.642 & -0.079 \\
\hline Tail & 0.021 & 0.021 & 0.017 & 1.246 & 0.232 & -0.015 \\
\hline Squatting & 0.490 & 0.278 & 1.767 & 0.093 & -0.090 & 1.071 \\
\hline
\end{tabular}

Table 8

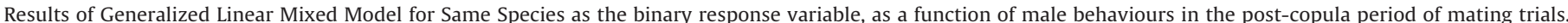

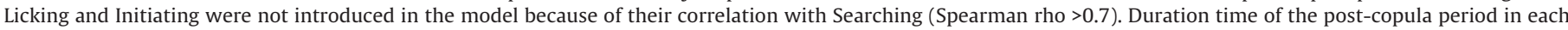

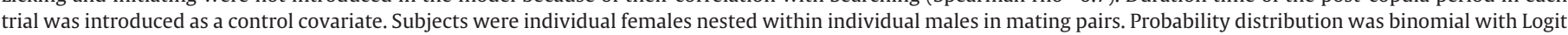

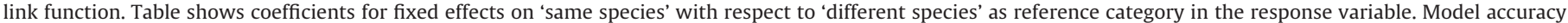
100.0\%. Random effects: males*females: Variance $\pm S E=7.132 \pm 2.972, Z=2.399 ; P=0.016 . \mathrm{N}=93$ cases.

\begin{tabular}{|c|c|c|c|c|c|c|}
\hline \multirow[t]{2}{*}{ Model term } & \multirow[t]{2}{*}{ Coefficient } & \multirow[t]{2}{*}{ Std. Error } & \multirow[t]{2}{*}{$\mathrm{t}$} & \multirow[t]{2}{*}{ Sig. } & \multicolumn{2}{|l|}{$95 \% \mathrm{CI}$} \\
\hline & & & & & Lower & Upper \\
\hline Intercept & -0.056 & 0.645 & -0.087 & 0.931 & -1.382 & 1.269 \\
\hline Duration Post. & 0.001 & 0.001 & 1.125 & 0.324 & -0.001 & 0.003 \\
\hline Searching & -0.183 & 0.207 & -0.884 & 0.386 & -0.613 & 0.246 \\
\hline Tongue flick & 0.059 & 0.035 & 1.662 & 0.103 & -0.012 & 0.129 \\
\hline
\end{tabular}

and heterospecific trials in the post-copula period. For females, only Searching resulted more common towards partners of the same species $(0.73 \pm 1.40$ vs. $0.02 \pm 0.15$; Table 9$)$. Behaviours correlated with Searching (Licking and Initiating) were non-significant when introduced one by one instead of Searching (not shown).

\section{Discussion}

Our results evidenced a weak pre-copulatory barrier between the two studied parapatric species, Mazama guazoubira and $M$. nemorivaga, leading to interspecific copulations between the two 
Table 9

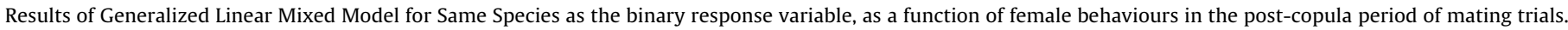

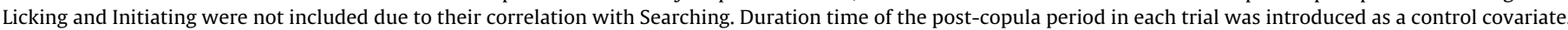

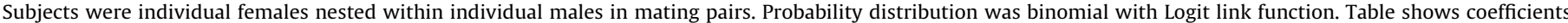

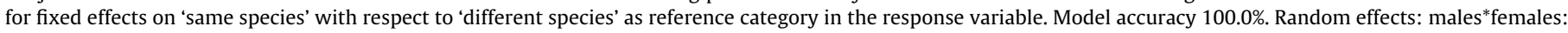
Variance $\pm \mathrm{SE}=6.970 \pm 2.933, \mathrm{Z}=2.376 ; \mathrm{P}=0.018 . \mathrm{N}=93$ cases.

\begin{tabular}{|c|c|c|c|c|c|c|}
\hline \multirow[t]{2}{*}{ Model term } & \multirow[t]{2}{*}{ Coefficient } & \multirow[t]{2}{*}{ Std. Error } & \multirow[t]{2}{*}{$\mathrm{t}$} & \multirow[t]{2}{*}{ Sig. } & \multicolumn{2}{|l|}{$95 \% \mathrm{CI}$} \\
\hline & & & & & Lower & Upper \\
\hline Intercept & -0.162 & 0.649 & -0.250 & 0.805 & -1.491 & 1.171 \\
\hline Duration Post. & 0.002 & 0.002 & -1.594 & 0.114 & -0.001 & 0.005 \\
\hline Search & 1.205 & 0.534 & 2.256 & 0.040 & 0.061 & 2.349 \\
\hline Tongue flick & -0.015 & 0.077 & -0.198 & 0.844 & -0.171 & 0.140 \\
\hline Tail & -0.015 & 0.018 & -0.841 & 0.403 & -0.050 & 0.020 \\
\hline
\end{tabular}

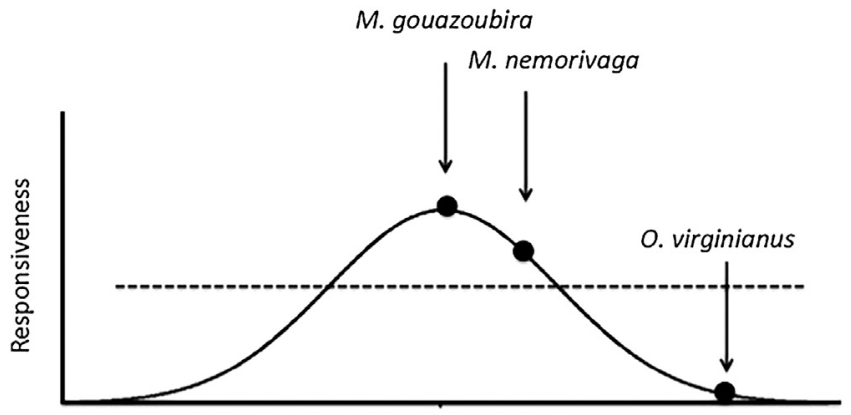

Phenotypic features of potential mates

Fig. 5. Hypothetical preference (responsiveness) function for a focal M. guazoubira female for variation in phenotipic features of potental mates belonging to same and other species. Choossiness is represented as the difference in preference between two values in the phenotipic trait. The horizontal dotted line depicts the threshold of preference above which female could accept copulation with potential mates, though with different responsiveness (based on Edwards, 2015).

brocket deer species, while the interactions with the outgroup control species (Odoloileous virginianus) clearly showed that brocked deer females strongly rejected the white-tailed deer male. The contrasting behaviour towards Odocoileous compared to that to the other brocket deer species, supports the weakness of premating barrier as a feature of the interaction between both morphologically similar species, rather than it being a general characteristic of female brocked deer behaviour.

According to the terminology proposed by Edwards (2015), our results indicate only a moderate choosiness (little variation within $\mathrm{Y}$ axis of preference, i.e. low slope) within the range of phenotypic variation (X axis) that includes the features of both brocket deer species, although they also show that white-tailed deer is clearly outside this range of preferences. Fig. 5 illustrates this point within a hypothetical preference function for M. gouazoubira females.

We found some male and female behaviours that associated with copulation outcome of trials. Males showed more interest in females in those trials that ended with copulation, mainly by initiating contact and performing related behaviours such as searching and mounting attempts. For females, several behaviours appeared to predict a copulation outcome. Females initiated contact by approaching the male, urinated and fanned their tails in those trials that finally led to copulation. These behaviours used by females during courtship (searching + squatting + tail fanning) appear related to chemical and visual signals that communicate sexual receptivity in ungulates (see e.g. Price 2008). Male and female behaviours also differed when trials were homo- or heterospecific, indicating species discrimination. Most courtship behaviours were more common towards members of the same species. For Tongue flick, however, the tendency was always the opposite. The role of tongue flick may be the inspection of sexual pheromones (Brennan, 2010) and its lower frequency might be interpreted as the result of the increment of other courtship behaviours. Significant differences in approaching behaviours maintained for females even after copulation, thus supporting some species-specific preference. We might expect males to be less selective than females when seeking copulations. Females incur higher costs than males from wrong matings and it is not common for males to reject a current mate in the hope of better future opportunities (see e.g. Barry and Kokko, 2010). Our results show that both male and female behaviour showed behavioural differences, although after copulation it was signifficant only for females. Also, we must take into account that some male behaviour may result in response to female signals, which in some cases may be difficult to perceive by human observers.

Despite behavioural evidences for species discrimination and preference for homospecific partners, some percentage of heterospecific trials ended with copulations (35.7\%; compared to $82.4 \%$ in homospecific trials). Very similar differences in copulation success were found in the three-spine stickleback (Gasterosteus aculeatus) but in this case at the level of ecotypes (McKinnon et al., 2004), which contrasts with the species level of our result. Interspecific mating is widely documented in many taxa (Rhymer and Simberloff, 1996; Barton, 2001; Schwenk et al., 2008) and it is also not rare among vertebrates (Ptacek 2000). The relevant issue is the meaning of the presence or absence of certain isolation mechanisms within the context of the evolutionary divergence of a species. For instance, it is well know how sika (Cervus nippon) and red deer (C. elaphus) interbreed (Putman and Hunt, 1993; Senn and Pemberton, 2009; Biedrzycka et al., 2012). In this case, the neat allopatry of their natural ranges means that any behavioural or physiological barrier between them should not be expected as the result of direct selection but simply as a by-product of divergence (Schluter 2001). In many cases, however, interspecific breeding occurs along hybrid zones and clines (Barton and Hewitt 1985). Some examples are Bombina bombina $x$ B. variegata (Szymura and Barton 1986), Gryllus firmus x G. pensylvanicus (Ross and Harrison, 2002) or Mus musculus x M. domesticus (Hunt and Selander, 1973).

Pre-mating isolating mechanisms between two species may be asymmetric (e.g. pupfishes: Kodric-Brown and West, 2014; woodrats: Shurtliff et al., 2013). For deer, preferences for interspecific male vocalizations differ for red and sika females (Wyman et al., 2014). However, our results did not show significant differences in copulation probability between the two heterospecific female-male combinations, suggesting that the barrier is probably similarly weak between both species.

In those cases when contact between species can occur and hybrids are less fit than pure species (Burke and Arnold, 2001), pre-zygotic isolation mechanisms are expected to be favoured by natural selection. Thus, the relevant question is why only a weak barrier has appeared between the two species, provided that contact is possible in nature.

Several circumstances and processes may be involved in this result. One of them might be the high resemblance between species. 
Mating preferences may evolve by phenotype matching, whereby individuals prefer a mate whose phenotype is similar to their own (Lacy and Sherman, 1983), which may favour interspecific mating in morphologically convergent species. In those cases, mate choice preferences may include interspecific traits (e.g. Ptacek, 1998). Potential similarities may also include chemical signals. Courtship interactions in many mammals greatly involve olfactory communication (Brennan, 2010). For brocket deer we do not know to which extent the convergence process that affected morphology has also led to convergent chemical signals that could facilitate interspecific attraction. The analysis of chemical compounds involved in courtship interactions is pending for these species.

Another relevant factor for the evolution of premating barriers is the frequency of interspecific mating contacts in the wild. Brocked deer are difficult to study in the wild because of their low density, elusive behaviour, habitat consisting on deep tropical forest, huge areas with difficult access, etc. Hence, information for their distribution ranges in the wild is rather rudimentary. It is assumed that they are parapatric, with a contact zone between both distribution ranges in the southern limit of the Amazon basin (Rossi and Duarte 2008). According to this distribution, contact might occur along a long strip of land of some $3000 \mathrm{~km}$ or more, but probably not in the rest of the very large distribution areas of both species. The extent to which this potential contact can favour selection against hybridization is difficult to estimate. If the chance for interspecific contact between both species would in general be low, a rare enemy effect (Dawkins, 1982) is expected. That means that the costs of rejection might not be outweighed by the potential costs of a wrong mating due to its low probability of occurrence. For males, rejection may incur potential costs of losing matings while wrong matings probably entail little costs (Barry and Kokko, 2010). For females, rejecting a mating may be costly when males engage in harassment behaviour, so that accepting a mate might be profitable in terms of time, energy and risks of injuries or predation (Clutton-Brock and Parker, 1995; Muhlhauser and Blanckenhorn, 2002; Parker and Birkhead, 2013); but also for females, wrong matings are potentially highly costly if leading to investment in non-successful offspring. Under this scenario, selection may favour post-mating rather than pre-mating discrimination before conception, i.e. sperm competition (Parker, 1970) and/or cryptic female choice (Eberhard, 1996). Postmating-prezygotic mechanisms have been shown to effectively reduce gene flow and thus act to maintain species boundaries if fertilization success in conspecific matings is relatively greater than that in heterospecific ones (Howard et al., 2009).

Sexual selection has an important role in maintaining species isolation by the evolution of signal divergence between species (Ptacek, 2000). Female choice is an important mechanism of both species recognition and intraspecific mate selection (Andersson, 1994; Kokko et al., 2003). However, sexual selection is not strong at the precopulatory stage in solitary species, either because malemale direct encounters are not so common and also because for females there are difficulties in assessing male quality and competitive ability without simultaneous comparison (see e.g. Pfennig, 1998). Such conditions of low intensity of sexual selection at the pre-copulatory stage may also hamper the evolution of specific signals for species recognition, and it is increasingly clear the existence of an evolutionary trade-off between pre- and post-mating sextraits (ungulates: Ferrandiz-Rovira et al., 2014; howler monkeys: Dunn et al., 2015).

Our result that multiple copulations within a trial can also occur in heterospecific trials, enforces the idea of little specific signals and wide range of female acceptance during oestrus, i.e. high responsiveness with little choosiness (sensu Edwards, 2015; see Fig. 5) at the pre-copulatory stage. But also, maintained female receptivity and acceptance during the duration of oestrus favours the evolu- tion of post-copulatory species recognition mechanisms during the interaction of sperm with the zona pellucida (Gadella 2010) and post-copulatory sexual selection by sperm competition (Parker, 1970) and/or cryptic female choice (Eberhard, 1996). Post-mating sexual selection produces signatures in the characteristics of male ejaculates and sperm morphology (see e.g. Parker and Pizzari, 2010). For example in mammals some sperm components appear to increase in an integrated manner associated with competition, sperm heads become more elongated, and the increase in sperm length was found to be associated with enhanced swimming velocity (Stockley, 2004; Tourmente et al., 2011). Some sperm features have been shown to respond to experimental selection for competitiveness (Firman and Simmons, 2011). Sperm morphology in brocked deer might support a role for sperm competition (Freneau and Duarte, 2001; Zanetti et al., 2010; Costa et al., 2011). However, a detailed study of post-mating species recognition and sexual selection in brocked deer species is lacking.

Finally, our study has important limitations mainly caused by captive conditions and the sample size of involved animals. Behaviour of brocket deer is very difficult to study in the wild, and the questions raised in this study require experimental manipulation. We have used the largest stock of captive brocked deer in the world but even so, sample size is limited. This is especially relevant provided that individual personalities and uncontrolled ontogenetic influences may promote elevated variability of the responses.

Further work should pursuit a better knowledge of brocket deer mating behaviour in the wild, a better delimitation of distribution areas and estimation of the probability of interspecific mating contacts in the wild, both in current times and in their past evolutionary history, as well as the possible existence of hybrids along the contact zone and the role of post-copulatory pre-zygotic barriers to maintain the isolation between both species.

\section{Acknowledgements}

We thank Antonio Carlos L. Andrade, Gessica C.H. Rodrigues and all personnel at NUPECCE for help during the experiments with the deer. C. Mateos provided statistical advice. Flavio Ford revised the English style. L. Corlatti and two anonymous reviewers made constructive comments that improved the manuscript. Financial support was from CAPES/CNPq (project A038_2013 to J.M.B.D. and J.C) and FAPESP (proc. 10/50748-3).

\section{References}

Andersson, M.A., 1994. Sexual Selection. Princeton University Press, Princeton, NJ, USA.

Barry, K.L., Kokko, H., 2010. Male mate choice: why sequential choice makes its evolution difficult. Anim. Behav. 80, 163-169.

Barton, N.H., Hewitt, G.M., 1985. Análisis of hybrid zones. Annu. Rev. Ecol. Syst. 16, $113-148$.

Barton, N.H., 2001. The role of hybridization in evolution. Mol. Ecol. 10, 551-568.

Biedrzycka, A., Solarz, W., Okarma, H., 2012. Hybridization between native and introduced species of deer in Eastern Europe. J. Mamm. 93, 1331-1341.

Birkhead, T.R., Brillard, J.-P., 2007. Reproductive isolation in birds: postcopulatory prezygotic barriers. Trends Ecol. Evol. 22, 266-272.

Black-Decima, P., Vieira Rossi, R., Vogliotti, A., Cartes, J.L., Maffei, L., Duarte, J.M.B. González, S., Juliá, J.P., 2010. Amazonian brown brocket deer Mazama nemorivaga (Cuvier 1817). In: Duarte, J.M.B., Gonzalez, S. (Eds.), Neotropical Cervidology: Biology and Medicine of Latin American Deer. FUNEP-IUCN, pp. 190-201.

Black-Decima, P., 2000. Home range, social structure, and scent marking behavious in brown brocket deer (Mazama gouazoubira) in a large enclosure. Mastozoologia Neotrop. 7 (1), 5-14.

Bradbury, J.V., Vehrencamp, S.L., 1998. Principles of Animal Communication. Sinauer, Sunderland.

Brennan, P.A., 2010. Pheromones and mammalian behavior. In: Menini, A. (Ed.) The Neurobiology of Olfaction. CRC Press/Taylor \& Francis, Boca Raton (FL).

Burke, J.M., Arnold, M.L., 2001. Genetics and the fitness of hybrids. Annu. Rev. Genet. 35, 31-52.

Clutton-Brock, T.H., Parker, G.A., 1995. Sexual coercion in animal societies. Anim. Behav. 49, 1345-1365. 
Costa, K.L.C., Matta, S.L.P., Gomes, M.L.M., Paula, T.A.R., Freitas, K.M., Carvalho, F.A.R., Silveira, J.A., Dolder, H., Mendis-Handagama, S.M.L.C., 2011 Histomorphometric evaluation of the neotropical brown brocket deer Mazama gouazoubira testis, with an emphasis on cell population indexes of spermatogenic yield. Anim. Reprod. Sci. 127, 202-212.

Curlewis, J.D., Loudon, A.S.I., Coleman, A.P.M., 1988. Oestrous cycles and the breeding season of the Père David's deer hind (Elaphurus davidianus). J. Reprod. Fertil. 82, 119-126.

Cursino, M.S., Duarte, J.M.B., 2016. Using sperm morphometry and multivariate analysis to di erentiate species of gray Mazama. R. Soc. Open Sci. 3, 160345 http://dx.doi.org/10.1098/rsos.160345.

Dawkins, R., 1982. The Extended Phenotype: The Long Reach of the Gene. Oxford University Press, Oxford, UK.

Dobzhansky, T., 1937. Genetics and the Origin of Species. Columbia University Press, New York.

Dougherty, L.R., Shuker, D.M., 2015. The effect of experimental design on the measurement of mate-choice: a meta-analysis. Behav. Ecol. 26 (2), 311-319.

Duarte, J.M.B., González, S., Maldonado, J.E., 2008. The surprising evolutionary history of South American deer. Mol. Phylogenet. Evol. 49, 17-22.

Dunn, J.C., Halenar, L.B., Davies, T.G., Cristobal-Azkarate, J., Reby, D., Sykes, D., Dengg, S., Fitch, W.T., Knapp, L.A., 2015. Evolutionary trade-off between vocal tract and testes dimensions in howler monkeys. Curr. Biol. 25, 1-6.

Eberhard, W.G., 1996. Female Control: Sexual Selection by Cryptic Female Choice. Princeton Univ. Press, Princeton, NJ.

Edwards, D.A., 2015. The description of mate choice. Behav. Ecol. 26 (2), 301-310.

Escobedo-Morales, L., Mandujano, S., Eguiarte, L.E., Rodríguez-Rodríguez, M.A., Maldonado, J.E., 2016. First phylogenetic analysis of Mesoamerican brocket deer Mazama pandora and Mazama temama (Cetartiodactyla: Cervidae) based on mitochondrial sequences: implications on Neotropical deer evolution. Mamm. Biol. 81 (3), 303-313, http://dx.doi.org/10.1016/j.mambio.2016.02.003.

Ferrandiz-Rovira, M., Lemaître, J.F., Lardy, S., López, B.C., Cohas, A., 2014. Do preand post-copulatory sexually selected traits covary in large herbivores? BMC Evol. Biol. 14, 79

Firman, R., Simmons, L.W., 2011. Experimental evolution of sperm competitiveness in a mammal. BMC Evol. Biol. 11, 19

Freneau, G.E., Duarte, J.M.B., 2001. Biometria testicular e caracteristicas seminais de veado-catingueiro (Mazama gouazoubira) mantidos em cativeiro em Porto Nacional - TO. Ars Veterinária 17, 1-15.

Futuyma, DJ., 2005. Evolution. Sinauer \& Associates, Inc., Massachusetts.

Gadella, B.M., 2010. Interaction of sperm with the zona pellucida during fertilization. Soc. Reprod. Fertil. Suppl. 67, 267-287.

Heckeberg, N.S., Erpenbeck, D., Wörheide, G., Rössner, G.E., 2016. Systematic relationships of five newly sequenced cervid species. PeerJ 4, e2307, http://dx. doi.org/10.7717/peerj.2307.

Howard, D.J., Palumbi, S.R., Birge, L.M., Manier, M.K., 2009. Sperm and speciation. In: Birkhead, T.R., Hosken, D.J., Pitnick, S. (Eds.), Sperm Biology An Evolutionary Perspective. Elsevier, Oxford, pp. 367-403.

Hunt, W.G., Selander, R.K., 1973. Biochemical genetics of hybridisation in European house mice. Heredity 31, 11-33.

Johnstone, R.A., 1997. The evolution of animal signals. In: Krebs, J.R., Davies, N.B. (Eds.), Behavioural Ecology. Blackwell, Oxford, pp. 155-178.

Kodric-Brown, A., West, R.J.D., 2014. Asymmetries in premating isolating mechanisms in a sympatric species flock of pupfish (Cyprinodon). Behav. Ecol. 25, 69-75.

Kokko, H., Brooks, R., Jennions, M.D., Morley, J., 2003. The evolution of mate choice and mating biases. Proc. Biol. Sci. 270, 653-666.

Lacy, R.C., Sherman, W., 1983. Kin recognition by phenotype matching. Am. Nat. $121,489-512$.

Liou, L.W., Price, T.D., 1994. Speciation by reinforcement of premating isolation. Evolution 48, 1451-1459.

Martins, G.S., 2015. Avaliacao da existencia de isolamento reprodutivo entre duas espécies de veados cinza (Mazama gouazoibira e Mazama nemorivaga) por meio de machos hibridos. MSc. Thesis. Faculdade de Ciencias Agrarias e Veterinarias, Universidade Estadual Paulista, Jaboticabal, 61 pp.

Mayr, E., 1963. Animal Species and Evolution. Harvard University Press, Cambridge.

McKinnon, J.S., Mori, S., Blackman, B.K., David, L., Kingsley, D.M., Jamieson, L., Chou, J., Schluter, D., 2004. Evidence for ecology's role in speciation. Nature 429, 294-298.

Morales-Piñeyrua, J.T., Ungerfeld, R., 2012. Pampas deer (Ozotoceros bezoarticus) courtship and mating behavior. Acta Vet. Scand. 54, 60-66.
Muhlhauser, C., Blanckenhorn, W.U., 2002. The costs of avoiding matings in the dung fly Sepsis cynipsea. Behav. Ecol. 13, 359-365.

Parker, G.A., Birkhead, T., 2013. Polyandry: the history of a revolution. Philos. Trans. R. Soc. Lond. B 368, 20120335.

Parker, G.A., Pizzari, T., 2010. Sperm competition and ejaculate economics. Biol. Rev. 85, 897-934.

Parker, G.A., 1970. Sperm competition and its evolutionary consequences in insects. Biol. Rev. Camb. Philos. Soc. 45, 525-567.

Pereira, J.R.G., Polegato, B.F., Souza, S., Negrão, J.A., Duarte, J.M.B., 2006. Monitoring ovarian cycle and pregnancy in brown brocket deer (Mazama gouazoubira) by measurement of fecal progesterone metabolites. Theriogenology 2, 387-399.

Pfennig, K.S., 1998. The evolution of mate choice and the potential for conflict between species and mate-quality recognition. Proc. R. Soc. Lond. B Biol. 265, $1743-1748$.

Price, E.O., 2008. Principles and Applications of Domestic Animal Behavior. An Introductory Text. CABI, Oxfordshire, UK.

Ptacek, M.B., 1998. Interspecific mate choice in sailfin and shortfin mollies. Anim. Behav. 56, 1145-1154.

Ptacek, M.B., 2000. The role of mating preferences in shaping interspecific divergence in mating signals in vertebrates. Behav. Process. 51, 111-134.

Putman, R.J., Hunt, E.J., 1993. Hybridization between red and sika deer in Britain. Deer 9, 104-110.

Rhymer, J.M., Simberloff, D., 1996. Extinction by hybridization and introgression. Annu. Rev. Ecol. Syst. 27, 83-109.

Ross, C.L., Harrison, R.G., 2002. A fine-scale spatial analysis of the mosaic hybrid zone between Gryllus firmus and Gryllus pennsylvanicus. Evolution 56, 2296-2312.

Rossi, R.V., Duarte, J.M.B., 2008. Mazama nemorivaga. In:. The IUCN Red List of Threatened Species.

Rossi, R.V., Bodmer, R., Duarte, J.M.B., Trovati, R.G., 2010. Amazonian Brown brocket deer Mazama nemorivaga (Cuvier. In: Duarte, J.M.B., Gonzalez, S. (Eds.), Neotropical Cervidology: Biology and Medicine of Latin American Deer. FUNEP-IUCN, pp. 202-210.

Ryan, M.J., Tailor, R.C., 2015. Measures of mate choice: a comment on Dougherty \& Shuker. Behav. Ecol. 26 (2), 323-324.

Samsudewa, D., Capitan, S.S., 2011. Reproductive behaviour of Timor deer (Rusa timorensis). Indones. Bull. Anim. Vet. Sci. 21, 108-113.

Schluter, D., 1998. Ecological speciation in freshwater fishes. In: Grant, P.R. (Ed.), Evolution on Islands. Oxford University Press, New York.

Schluter, D., 2001. Ecology and the origin of species. Trens Ecol. Evol. 16 (7), $372-380$.

Schwenk, K., Brede, N., Streit, B., 2008. Introduction. Extent, processes and evolutionary impact of interspecific hybridization in animals. Philos. Trans. R. Soc. B Biol. Sci. 363, 2805-2811.

Senn, H.V., Pemberton, J.M., 2009. Variable extent of hybridization between invasive sika (Cervus nippon) and native red deer (C. elaphus) in a small geographical area. Mol. Ecol. 18, 862-876.

Shah, K.B., Tripathy, S., Suganthi, H., Rudraiah, M., 2014. Profiling of luteal transcriptome during prostaglandin F2-alpha treatment in buffalo cows: analysis of signaling pathways associated with luteolysis. PLoS One 9 (8), e104127, http://dx.doi.org/10.1371/journal.pone.0104127.

Shurtliff, Q.R., Murphy, P.J., Yeiter, J.D., et al., 2013. Experimental evidence for asymmetric mate preference and aggression: behavioral interactions in a woodrat (Neotoma) hybrid zone. BMC Evol. Biol. 13, 220.

Stockley, P., 2004. Sperm competition in mammals. Hum. Fertil. 7 (2), 91-97.

Szymura, J.M., Barton, N.H., 1986. Genetic analysis of a hybrid zone between the fire-bellied toads, Bombina bombina and Bombina variegata, near Cracow in southern Poland. Evolution 40, 1141-1159.

Tomkins, T., Bryant, M.J., 1974. Oestrous behaviour of the ewe and the influence of treatment with progestagen. J. Reprod. Fertil. 41, 121-132.

Tourmente, M., Gomendio, M., Roldan, E.R.S., 2011. Sperm competition and the evolution of sperm design in mammals. BMC Evol. Biol. 11, 12.

Trivers, R.L., 1972. Parental investment and sexual selection. In: Campbell, B. (Ed.), Sexual Selection and the Descent of Man, 1871-1971. Aldine, Chicago, pp. 136-179.

Wyman, M.T., Locatelli, Y., Charlton, B.D., Reby, D., 2014. No preference in female sika deer for conspecific over heterospecific male sexual calls in a mate choice context. J. Zool. 293, 92-99.

Zanetti, E.S., Duarte, J.M.B., Polegato, B.F., Garcia, J.M., Canola, J.C., 2010. Assisted reproductive technology. In: Duarte, J.M.B., Gonzáles, S. (Eds.), Neotropical Cervidology. FUNEP, Jaboticabal, pp. 255-270. 